\title{
American Vs Iranian University Websites: A Critical Discourse Analysis of About Pages
}

Reza Ghafar-Samar, ShabnamMokhtarnia

TarbiatModares University, PO Box 14115-355 Tehran, Iran

E-mail: rgsamar@modares.ac.ir

TarbiatModares University, PO Box 14115-355 Tehran, Iran

E-mail: smokhtarnia@gmail.com

\begin{abstract}
In today's competitive world, official websites provide great venues for colleges and universities to express their institutional identity, "an abstract representation of the complexity of the whole organization" (Seidl 2005, p. 82) in order to leave an overriding impression on their potential clients and achieve institutional legitimacy and political power (DiMaggio \& Powell, 1983).Thecombination of language and image areingredientsuniversity websites employ to promotetheir institutions and establish a distinct identity(e.g.,Anctil, 2008). Different sociocultural contexts, nonetheless, bear the potential to affect the way academic institutions represent their organizations on their official websites.This study, therefore,was an attempt to explore how top six Iranian and American universities used language to represent themselves on the About pages of their institutional websites. The results revealed significant differences in the way these universities promoted themselves on their official partially related to larger socio-cultural forces functioning in their societies.
\end{abstract}

Keywords: Institutional identity, Official websites, About pages, Colleges and universities

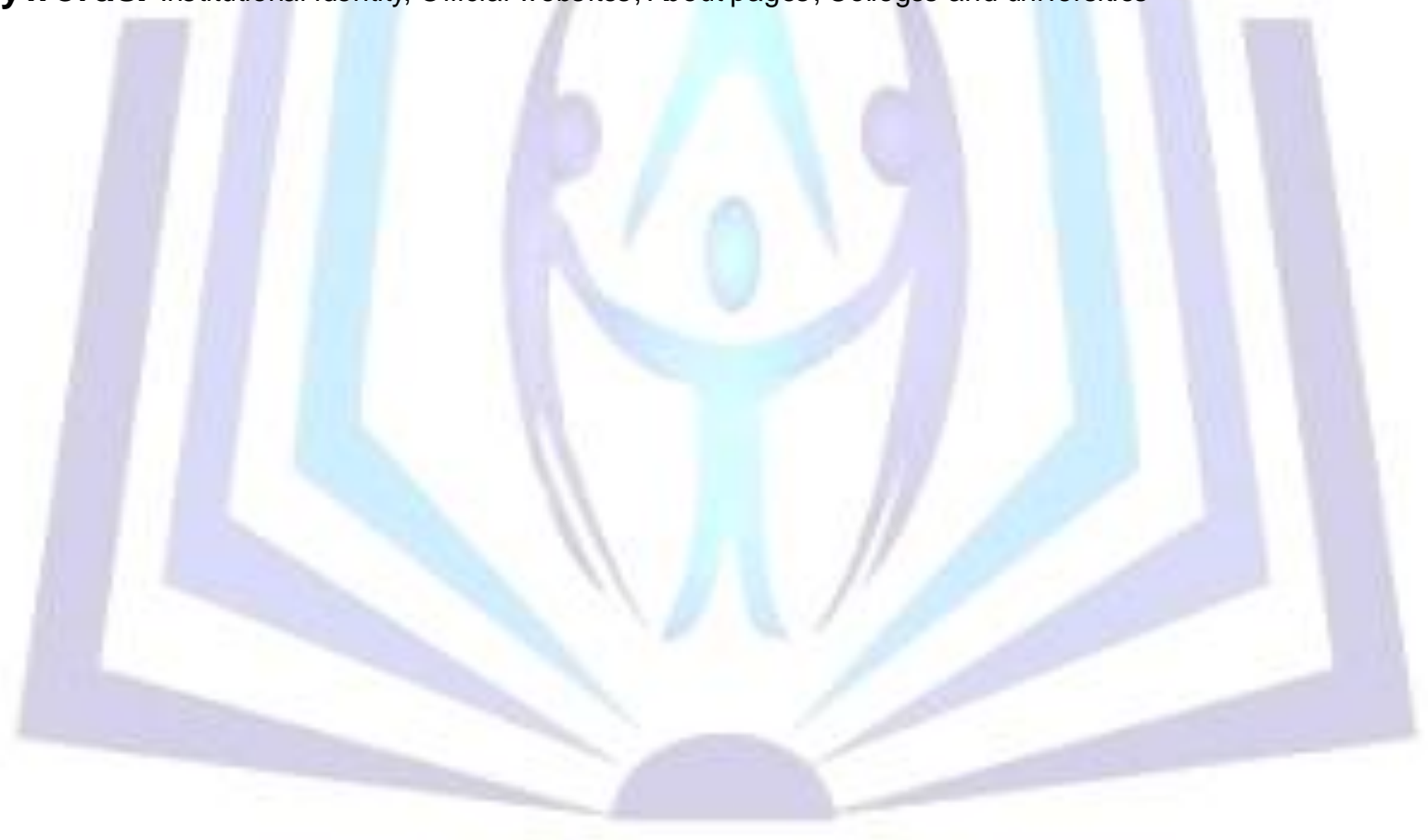

\section{Council for Innovative Research}

Peer Review Research Publishing System

\section{Journal: Journal of Social Sciences Research}

Vol. 8, No. 3

jssreditor.cir@gmail.com

www.jssronline.com 


\section{INTRODUCTION}

In today's competitive world where colleges and universities vie for establishing a distinct status in order to distinguish themselves from rival organizations, expressing institutional identity through official websites is a great asset at the disposal of such academic institutions. Institutional identity, "an abstract representation of the complexity of the whole organization" (Seidl 2005, p. 82),provides a general guideline for organizational practices and decisions (Luhman n 2000). As "a self-description of the organization," institutional identity provides "a sense of unity" on the basis of which the organization "observes its different parts as related to each other (Seidl 2005, p. 82)" and represents itself to other organizations.

A principal channel for communicating institutional identity in today's world is official websites on which organizations including colleges and universities represent a self-descriptive text of themselves as a unified social system. Colleges and universities welcome the use of institutional websites due to their capacity to rapidly communicate a momentous amount of information to a potentially massive audience (Abrahamson, 2000; Adelman, 2006; Anctil, 2008; Ashburn, 2007; Boyles, 2007). It is through a combination of language and image that colleges and universities attempt to market their institutions in order to establish a distinct identity and create a strong impression on theirpotential target audiences including future students (Anctil, 2008; Askehave, 2007; Hossler, 1999; McKnight \&Paugh, 1999).

Like other organizations, colleges and universities compete not only for customers (i.e., students) and resources (i.e., tuition dollars) but also for institutional legitimacy and political power which translates into economic and social fitness (DiMaggio \& Powell, 1983). They utilize text and image to position and distinguish themselves from other institutions, publicize their efforts, and draw the attention of diverse audiences including prospective students, donors, and alumni (Urciuoli, 2003). Universities, as a result, rely on a variety of tactics in order to create a distinctive image as a means to enhance their identity and reputation in order to increase their admission and recruitment.

Little research, however, exists as to whether different socio-cultural contexts have an impact on the way universities utilize discourseto represent themselveson their institutional websites. The United States of America and Islamic Republic of Iran are two example countries with different socio-cultural and political contextswith the potential to have different impact on the waytheir academic institutions represent themselves online. The purpose of this study, accordinglywas to understand how Iranian and American universities usedlanguage to represent themselves on the About pages of their institutional websites. More specifically researchquestionsaddressed in this study were as follows:

In what ways do Iranian and American universities use language to represent themselves on the About pages of their institutional websites?

- Is there any difference between Iranian and American universities in the way they represent themselves on the About pages of their institutional websites?

- Is there any difference between Iranian and American universities in the way they represent themselves in the opening of About pages of their institutional websites?

\section{METHOD}

Data for the present study was gathered from six top universities of the Islamic Republic of Iran and the United States of the America as identified by the website of 2012 University Web Ranking (Retrieved from http://www.4icu.org/ir/andhttp://colleges.usnews.rankingsandreviews.com/best colleges/rankings/national-universities, 26/04/2012). The selected universities are presented in Table 1.

\section{Table 1.Top six Iranian and American universities}

\begin{tabular}{|c|c|c|c|c|c|}
\hline \multicolumn{3}{|c|}{ Top Six Iranian Univers ities } & \multicolumn{3}{|c|}{ Top Six American Universities } \\
\hline 1 & $\begin{array}{l}\text { University of } \\
\text { Tehran }\end{array}$ & $\begin{array}{l}\text { http:/www.ut.ac.ir/en/contents/UT- } \\
\underline{\text { OverView/UT.Overview.html }}\end{array}$ & 1 & $\begin{array}{l}\text { Harvard } \\
\text { University }\end{array}$ & http://www.harvard.edu/about-harvard \\
\hline 2 & $\begin{array}{l}\text { Ferdowsi } \\
\text { University of } \\
\text { Mashhad }\end{array}$ & http://www.um.ac.ir/?new lang=eng\# & 2 & $\begin{array}{l}\text { Princeton } \\
\text { University }\end{array}$ & http://www.princeton.edu/main/about/ \\
\hline 3 & $\begin{array}{l}\text { Tehran } \\
\text { university of } \\
\text { medical } \\
\text { sciences }\end{array}$ & $\begin{array}{l}\text { http://www.tums.ac.ir/english/content/?c } \\
\underline{\text { ontentlD=2 }}\end{array}$ & 3 & Yale University & http://www.yale.edu/about/index.html \\
\hline 4 & $\begin{array}{l}\text { ShahidBehesht } \\
\text { i University }\end{array}$ & $\begin{array}{l}\underline{\mathrm{http}}: / / \text { en.sbu.ac.ir/default.aspx?TablD }=6 \\
\underline{4}\end{array}$ & 4 & $\begin{array}{l}\text { Columbia } \\
\text { University }\end{array}$ & $\begin{array}{l}\text { http://www.columbia.edu/content/about } \\
\underline{\text { columbia.html }}\end{array}$ \\
\hline
\end{tabular}




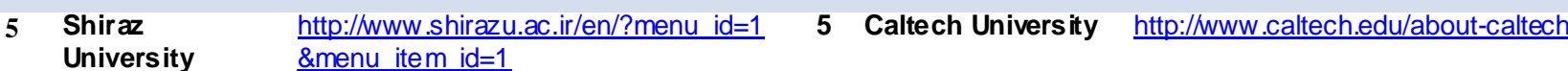

6 Mashhad University of

Medical

Sciences http:/www.mums.ac.ir/admission/en/ove

rview

In this study an attempt was done to content analyze the About pages of top six American and Iranian universities in order to investigate how these universities presented their institution to the general public. This comparison would provide a golden opportunity to see whether different socio-political and cultural contexts could have animpact the language academic organizations em ploy to represent themselves on their institutional websites.

Having collected data from the About pages of the above-mentioned websites, they were subjected to content analysis in order to investigate any possible differences in the way the selected universities introduced their institution online.

\section{DATA ANALYSIS}

The content analysis of theAbout pages oftop six American and Iranian universitiesindicated that the About pages ofthe official websites of those academic institutions essentiallycontained self-promotional language for establishing a sense of prestige by referring to the cherished traditions of the institutions and their omamented histories.Topics that were mentioned on their About pages includedthe age of the institution (founding year), size and beauty of the campus (i.e., acres, number of buildings), and award-winnings.

Considering top six Iranian universities, almost all of them initiated their About pages with presenting an ample account of the history and origin of their institution, its location, age, and ranking, followed by a boastful enumeration of theraw statisticsabout the number of faculties, staff, faculty members, students, libraries, research centers and programs offered at both undergraduate and graduate levels. Besides such brief overviews, each university provided additional hyperlinks to refer their audiences to additional information about their organization.

The first ranking Iranian universityas identified by 2012 University Web Ranking (Retrieved from http://www.4icu.org/ir/)was University of Tehran, as brought in Figure 1 with the maximum number of subpages among the studied Iranian universities with the titles of UT Overview, Cultural and Academic Activities, Facts and Figures, Guest House, History, Libraries and Publication Center, Office of International Relations, Present Status, andUT Organization (See Figure 1). This university started it's About page with referring to the founding year of the university, the subjects that were taught at that time and the way it evolved into a modem school. As a picture caption at this page, this university also boasted aboutits status as the oldest, largest, and best university of the countrywith a ranking of 368 among the top universities around the world in 2009.

In its firstsubpage, Cultural and Academic Activities, it pointed out to its major cultural and academic activities as including cooperation with foreign countries in holding international conferences, seminars and workshops. It also mentioned the number of its scientific associations, student unions,student clubs andresearchers who were awarded in national and international events. In thesection of Facts and Figures, in addition, it referred toits year of establishment, size and location of the university, number of campuses, faculties, departments, faculty members, students, adminis trative staff, graduates in the previous years, research centers, labs, scientific journals, membership in intemational associations/unions, international agreements and the number of artistic and athletic medals won in the international competitions .

Following these came the description of the guest house, its location, the facilities it provided, and the manner in which it could be reserved by international guests and students. The subsequent sections i.e., History andLibraries and Publication Centerwere concerned with providing a comprehensive account of the history of UT and the number and quality of its libraries and publication centers. At the subpage of Office of International Relations, in addition, it introduced this particular office as a link between UT and international students, faculty members and researchers. In addition, on the page ofPresent Status, it reiteratedthe statistics related to the number of colleges, faculties, departments, campuses, personnel, students, and publishedjournals.

Finally, in the last section, i.e., UT Organization, some information regarding the organizational structure of the university as to the positions of President, Vice President for Research and Technology, Vice-President for Planning and Information Technology, Vice-President for Student and Cultural Affairs, and Vice-President for International Affairs and Public Relations was provided. In this section, while a brief introduction of the responsibilities of each organizational position was provided, no reference to the picture, biography and personal and academic infomation of those positions was included. 


\section{ISSN 2321-1091}

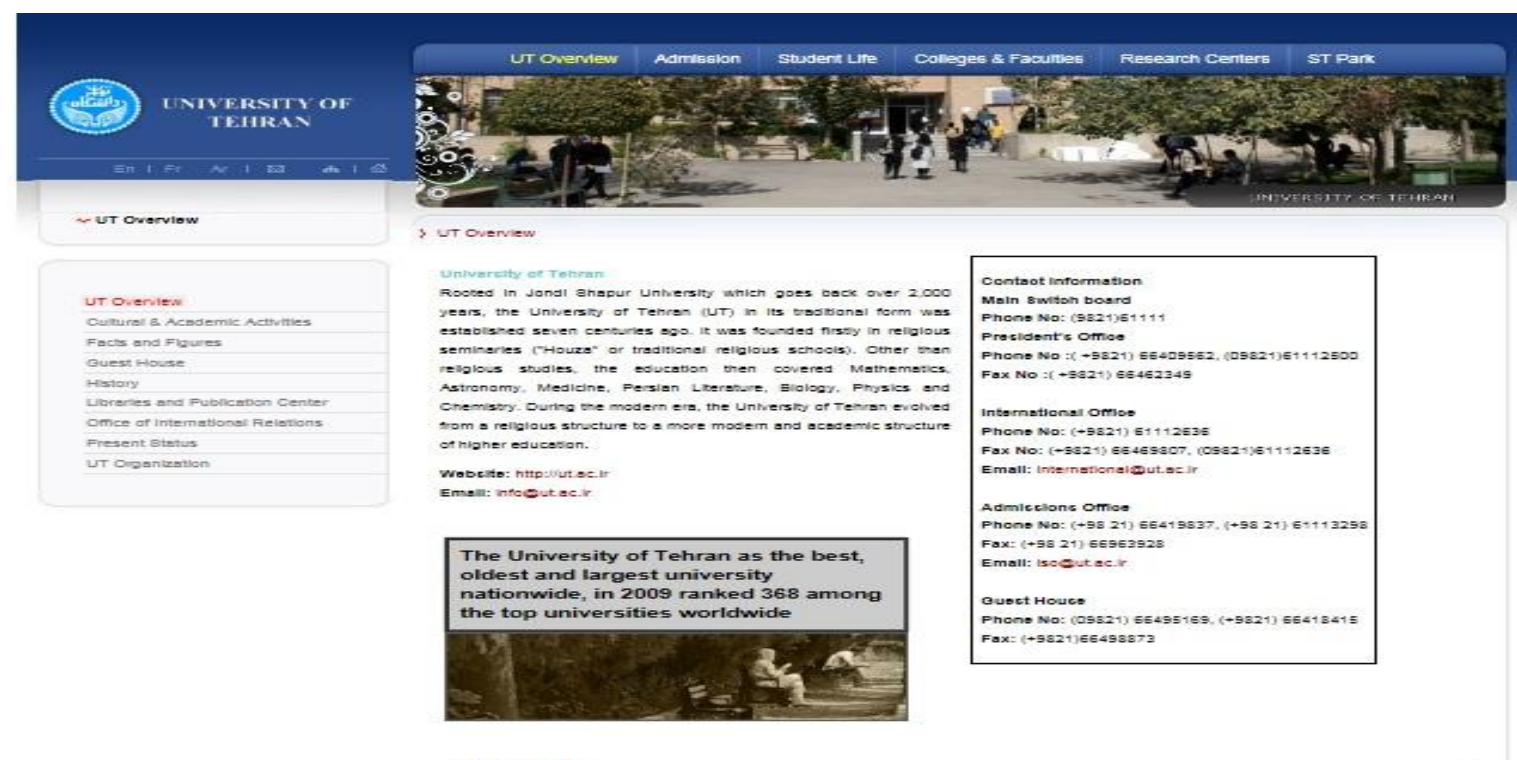

Figure 1 : University of Tehran About Page

The second ranking Iranian university was Ferdowsi University of Mashhad with just one page of "A Word from the President" as its only subpage(Figure 2). The website of this university commenced its About page with explaining the origin of the name of the university: "Ferdowsi University of Mashhad (FUM) is a state university named after the great epic poet and scholar Ferdowsi whose Shahnameh (The Book of Kings) is a well-known classical chef-d'oeuvre in Persian literature." Themes that were addressedon thiswere university's location, age, ranking in the country in general and in the northeast part of Iran in particular, the number of its faculties, staff, faculty members, and students. In addition, on this page, this university mentioned some of its specific departments as centers for excellence and highlightedthe university's success in attracting intemational students. It concluded the page by stating its mission as to striving to "expand minds, foster new ideas, and perpetuate intellectual and personal growth."

Among thetop six Iranian universities surveyed, Ferdowsi University of Mashhad was the only one that enclosed a page as A Word from the President as part of its About page to restate an overview of the university's servicesand its mission statementas to aiming to"equip the students with substantial resources" in order to "join a legacy of thinkers, leaders, and global citizens". Comparing the university's achievements in two periods of pre- and post Islamic revolution was in additiona common thread among Iranian universities run through the About page of them includingFerdowsi University of Mashhad.
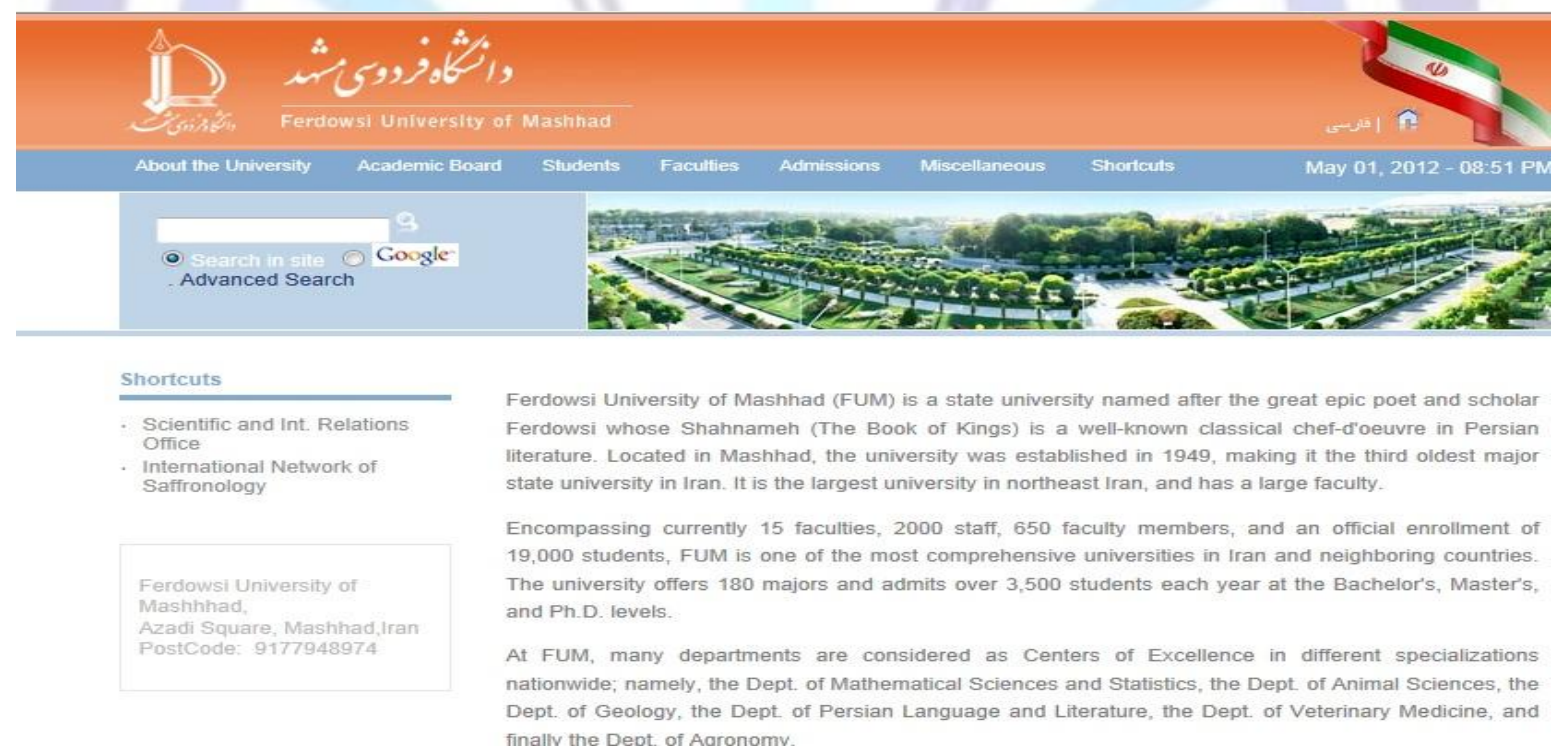

finally the Dept of Aaronomv.

Figure 2. Ferdowsi University of Mashhad About Page

The third ranking Iranian university was Tehran University of Medical Sciences with a single About page containing five parts of Introduction, Historical Sketch, Quick Facts about T.U.M.S., Academic Overview, and International Relations Further Information, all brought onthe same page without being hyperlinked (Figure 3). This university initiated its About page neither by referring to its history nor its mission statement but an essay-type introductory statement: "This introduction provides basic information about Tehran University of Medical Sciences and Health Services(T.U.M.S.); 
offered courses, requirements for admission, a flavor of life on the campus, and the academic, sport, and social facilities available." In subsequent sections, some information was provided regarding the commitment of the university for providing a working and leaming environment for students and researchers with a "perspective of high ethical and spiritual codes of behavior."

In addition, some information onthe history of the university, its age, size, and ranking as an outstanding medical center in Iran, the number and excellenceof theadmitted students andcourses offered andthe amount of financial resources provided by the government was providedwhile bragging about the number of educational and health research centers, teaching hospitals, libraries, hospitals, and sport facilities this university has all around the country. This university concluded its About page withdeclaring its readiness for joining "research projects and collaborations with universities all around the world." It is worth mentioning that a page on Message from the Chancellor was also included in the institution's website but as a subpage of the main website nottheAbout page its elf.

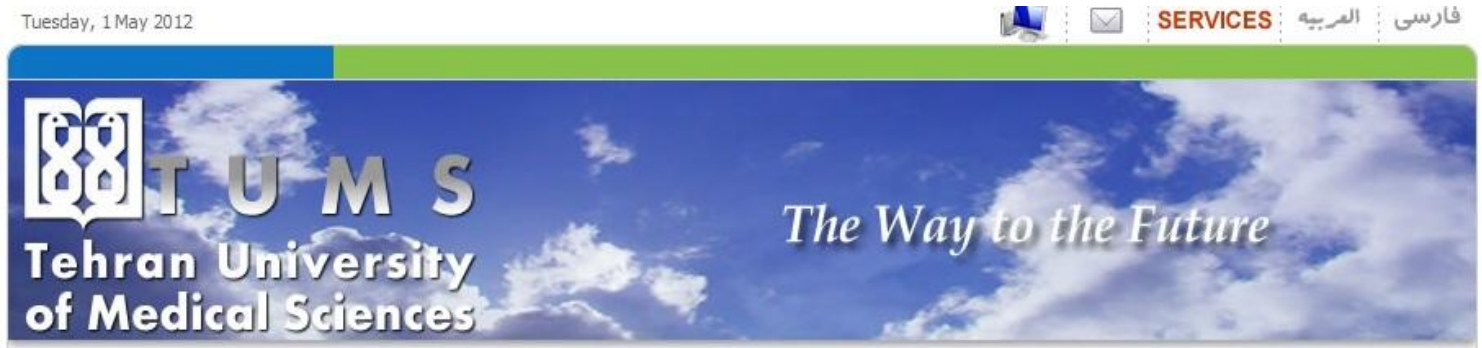

\begin{tabular}{|l|}
\hline Schools \\
\hline International Campus \\
\hline University \\
\hline Research Centers \\
\hline Site Map \\
\hline Museum of History of Medical \\
\hline Hospitals \\
\hline Tums Press \\
\hline Digital Library \\
\hline Tums Journals \\
\hline Alumni Office \\
\hline International Relations Office \\
\hline
\end{tabular}

About TUMS

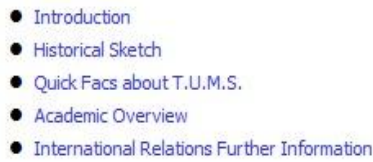

INTRODUCTION - This introduction provides basic information about Tehran University of Medical Siences and Health Services (T.U.M.S.); courses offered, requirements for admission, a flavor of life on the campus, and the academic, sport, and social facilities available. This should give an overview and help you recognize the benefits and advantages of studying here. Each year many hundreds of new researchers and students start their careers at this University. In doing so they embark upon a journey that is challenging and rewarding, and above all, they will have perspective of high ethical and spiritual codes of behavior. .T.U.M.S. is committed to providing a working and learning environment. All members of the University are responsible for ensuring that you take advantage of various facilities, and that you are encouraged and supported in any legitimate complaint.

Figure 3. Tehran University of Medical Sciences About Page

The fourth ranking Iranian university was ShahidBeheshti University with one single About page started with an extensive account of the history of the university followed by portraying the current status of the university in terms of the number of offered postgraduate programs and faculties which have become active since 1978 (Figure 4). The page was wrapped up by boasting about the "outstanding" and "rewarding" academic environment provided by this university not only in the country but also in the region as stated: "the University and the members of the academia are at the forefront of world research in many fields and the teaching is informed by the very latest developments in each discipline."

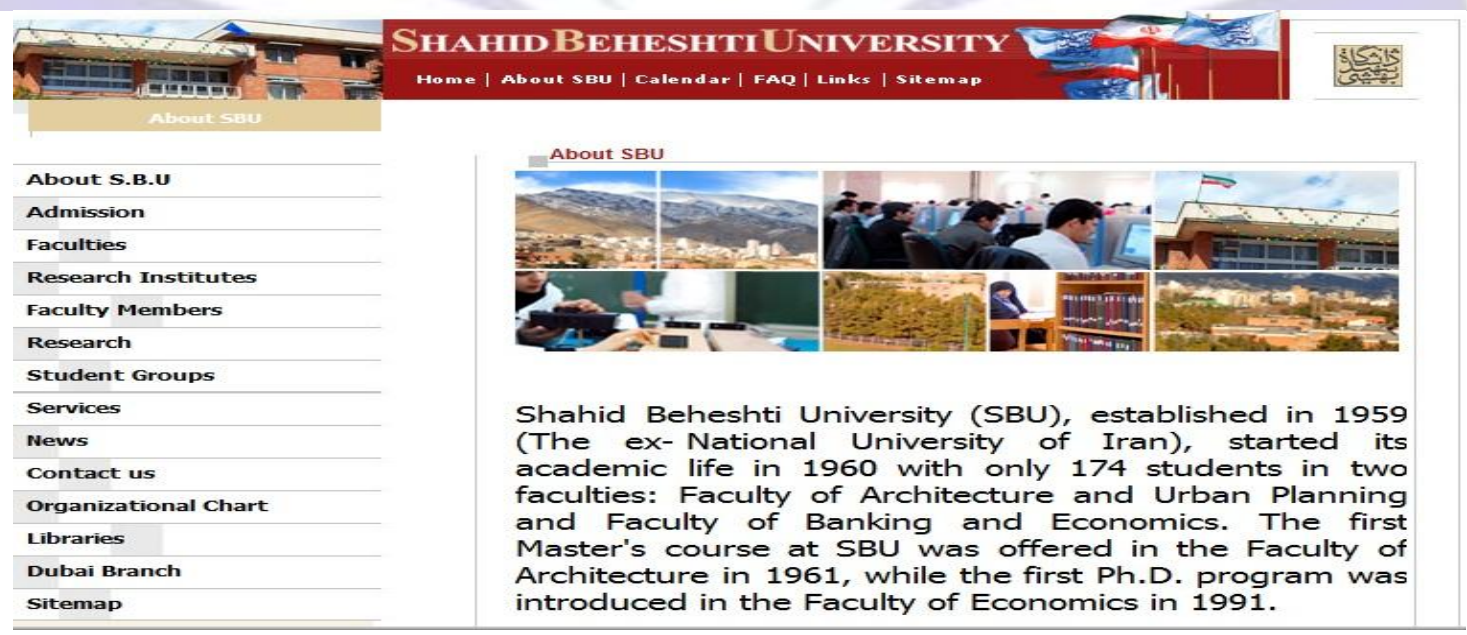

Figure 4.ShahidBeheshti University About Page 


\section{ISSN 2321-1091}

The fifth university surveyed in this study was Shiraz University whichincorporated two pages of History and Welcome to Shiraz as two constituent parts of its About page. The page of History dedicated three paragraphs to the past of the university regardingthe periods of before and after the Islamic revolution, while concluding with a single paragraph on the present status of the university specifying the number students attended there and the number of undergraduate, graduate, and post-graduate programs offered. The second page, Welcome to Shiraz, presented an all-embracing account of the history of the province of Fars and the city of Shiraz accompanied by some additional links to the historical monuments of the city such as Arg (citadel) of Karim Khan, Jame' Atiq Mosque, Vakil Bazaar, Qur'an Gate, Afifabad Garden, Holy Shrines, Eram Garden, The Tomb of Hafez, and The Tomb of Sa'di.

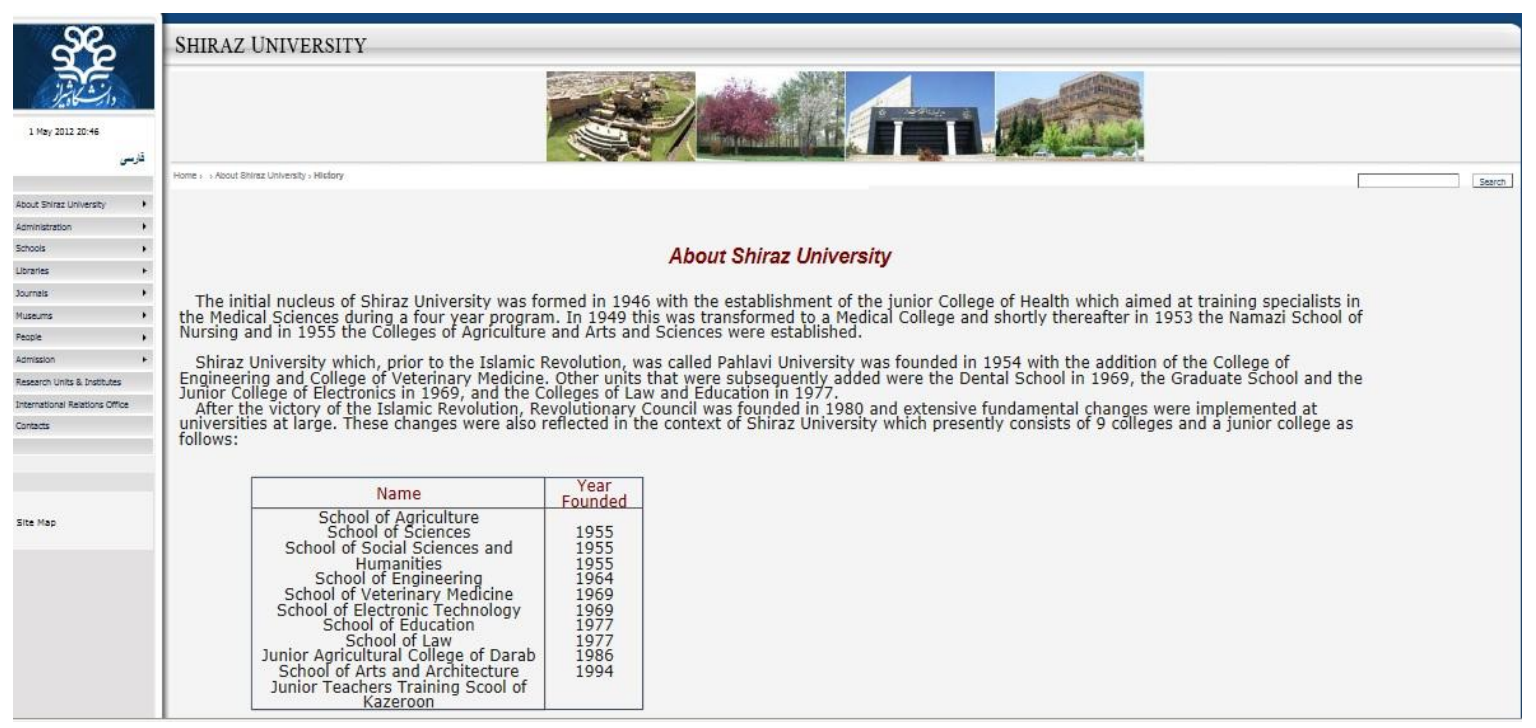

Figure 5.Shirza University About Page

The last studieduniversity was Mashhad University of Medical Sciences with anAbout page which composed of three subpages of History, Mission and Overview; quite interestingly having the History page, not the Overview as the first subpage. The history page started with a very brief account of the times of yore of the university wrapped up by an account of the current number of faculties, hospitals, rural and urban health centers, teaching staff, specialists, and employees making the university largest university of Medical Sciences in the country. The second page was devoted to expressing the mission of the university as to

provide highly standard education to... students and improve... community health. ... by providing educational opportunities in many biomedical and clinical sciences, by conducting research on the variety of areas, by providing comprehensive, innovative and cutting-edge patient care, and by facilitating public access to education and care through its public service and outreach activities.

In the last page, i.e., Overview, the founding year of the university, its location, origins, the current vision, motto, guiding values and key benefits to the region and country were evidently mentioned.

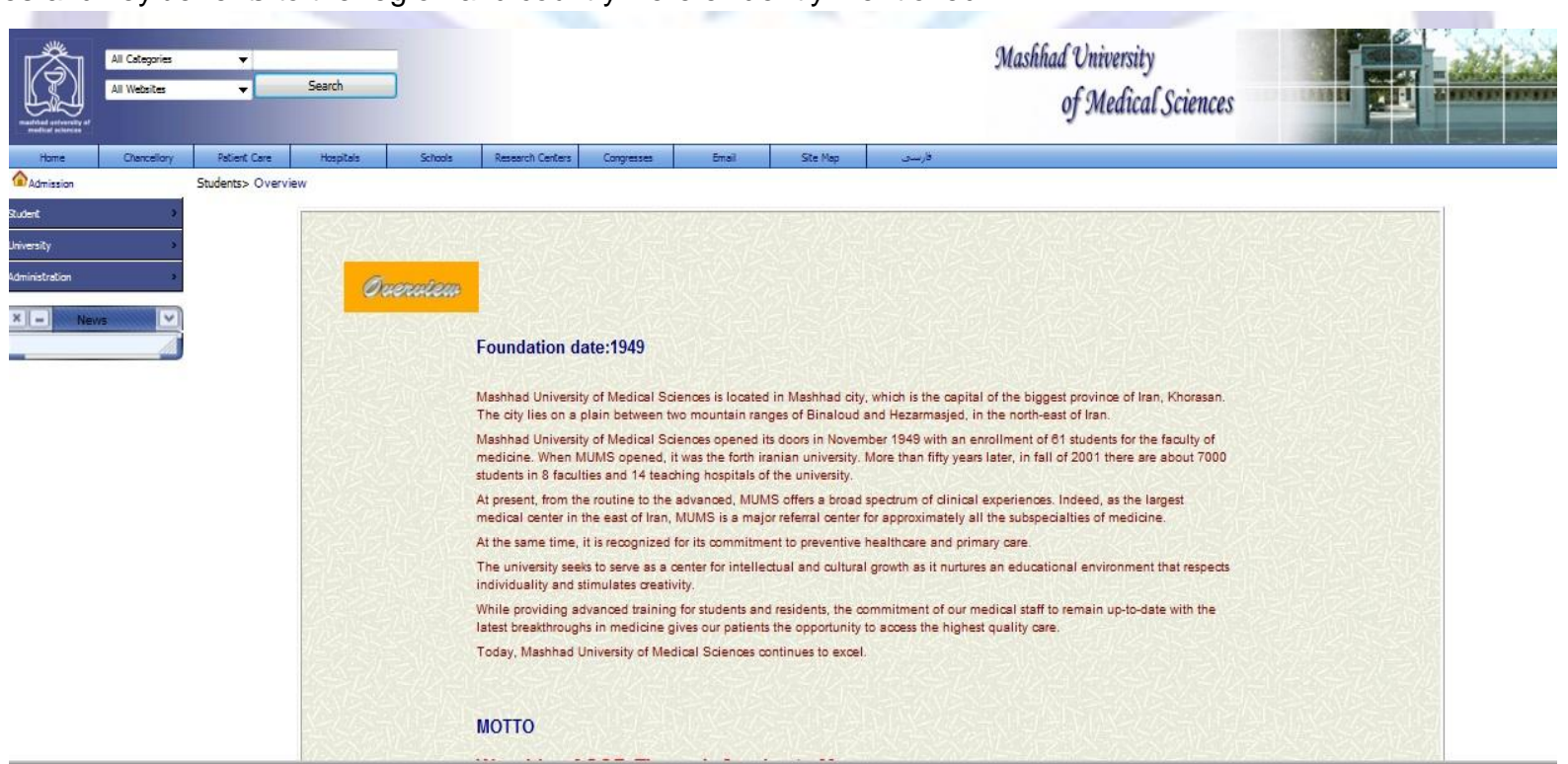

Figure 6. Mashhad University of Medical Sciences About Page 
AmongAmerican universities, Harvard was the first ranking university as identified by 2012 University Web Ranking (Retrieved from http://colleges.usnews.rankingsandreviews.com/bestcolleges/rankings/national-universities) was University of Harvard which contained five sub-pages of About Harvard, Harvard at a Glance, FAQ, Academic Experience, Maps and Directions, Harvard President and leadership. University of Harvard commenced this page with its mission statement as to being "devoted to excellence in teaching, learning, and research, and... to developing leaders in many disciplines who make a difference globally" with faculties "engaged with teaching and research to push the boundaries of human knowledge". Claiming to generously offer a financial aid program with over $\$ 160$ million, awarded to more than $60 \%$ of its undergraduate students, this university boasted about being the oldest university in the United States while mentioning its year of establishment and the number of schools, students and alumni around the world.

In the next page, Harvard at a Glance, the university published a full report of the number of its faculties and schools, students, professors, living alumni, Nobel laureates, library collection, andthe magnitude of the university income, expenses, and endowment, in addition to mentioning school color and motto. In the next page, FAQ, Harvard provided answers to general questions such as how to apply to Harvard or what the mission statement of Harvard is in addition questions about financial resources and facilities of this university. At the page of Academic Experience, Harvard provided embeddedlinks to allits faculties and schools for those who might be interested in contacting them or applying to their programs.At the page of Maps and Directions, in addition, the university offered maps of its schools, theaters, hospitals, clinics, museums, libraries, and athletic facilities. Finally, at the page of Harvard's President and Leadership, this university presented a brief introduction to the leadershipvision ofthe university accompanied witha brief introduction to the president of the university while providing some links to the office and dean of each school.

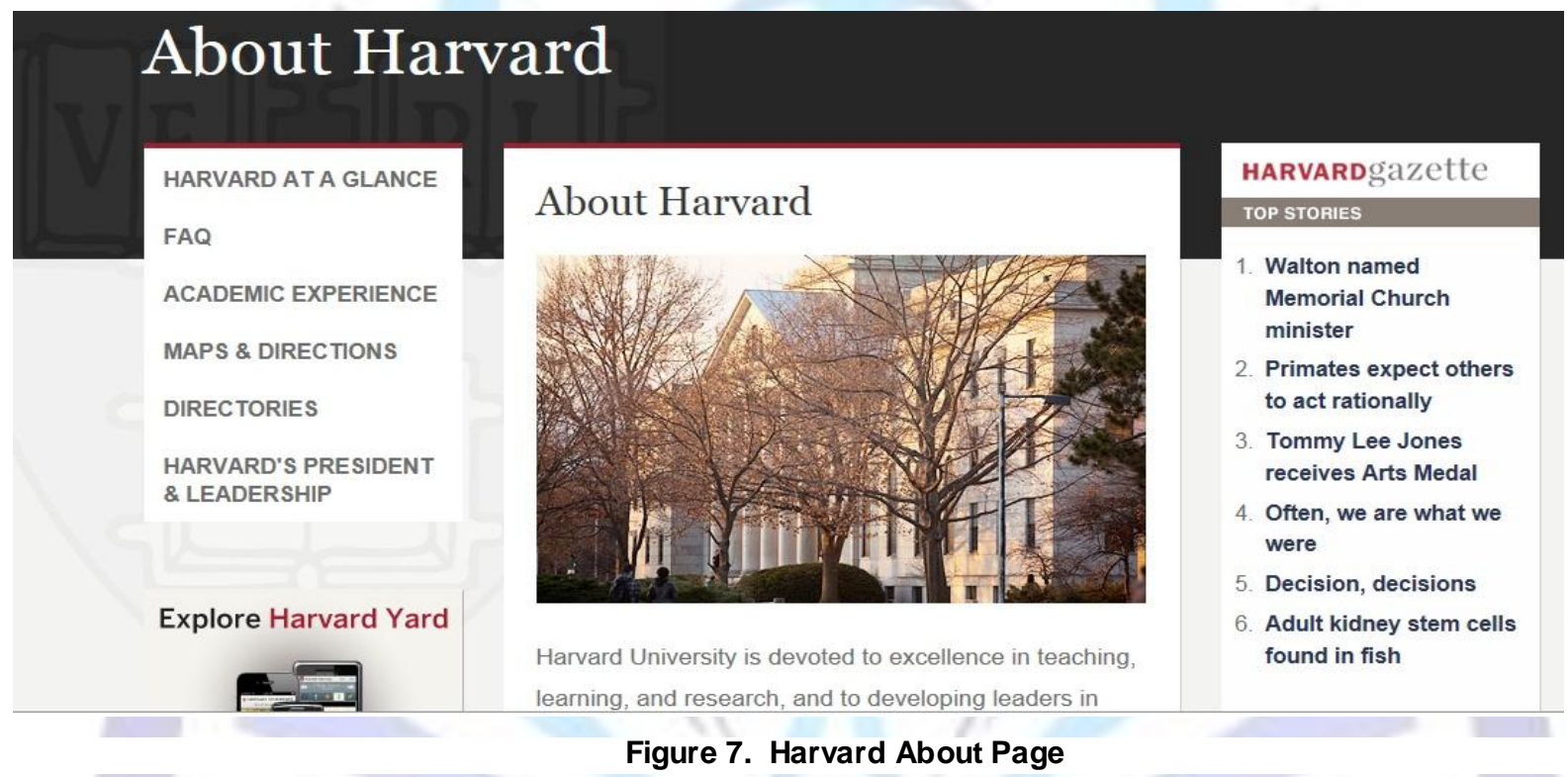

Princeton University was the second ranking American university with six main sub-pages of Overview, Facts and Figures, Princeton's History, University Governance, Our Neighborhood, and About This Site. Introducing itself as "a vibrant community of scholarship and leaming that stands in the nation's service and in the service of all nations" this university ascertained its position in its main About page as to the fourth-oldest college in the United States seeking to "achieve the highest levels of distinction in the discovery and transmission of knowledge and understanding."This very page then concluded with a succinct illustration of the number of faculty members and students at both underg raduate and graduate levels while magnetizing the audience with the university's generous financial aid program ensuring that "talented students from all economic backgrounds can afford a Princeton education".

In its second page, Overview, it mentionedits year of establishment, who the president was, university location, size of the main campus, the residential college system, the number of faculties, the ratio of the undergraduate students to faculties, departments, interdisciplinary certificate programs, library holdings, student enrollment, undergraduate students on financial aid, and the countries intemational students came from, etc. In the following section, i.e., Facts and Figures, the university provided some information on buildings and architects, honorary degrees, national humanities medals, national medals of science, and Nobel prize winners. On the History page, afterwards, the university provided a glance of Princeton's university's history while referring to the American Revolution and Princeton's timeline as well.

In the next page, University Governance, a concise portrayal of the university's president along with that of the trustees of Princeton university, Princeton's academic officers and offices of the corporation, and the council of the Princeton university communitywas offered. On the page ofOur Neighborhood, after thatthe Princeton area was depicted as having "tree-lined streets, specialty shops, restaurants, and parks" emitting"a friendly and safe atmosphere," the McCarter Theatre Centerwas widelyextolled for the arts lovers. In addition, some further links were offered for getting familiar with 
local activities and resources, the office of Community and Regional Affairs and getting around campus. Finally, in the About This Site, the website of the university, its history, and a guide to quick navigation was provided.

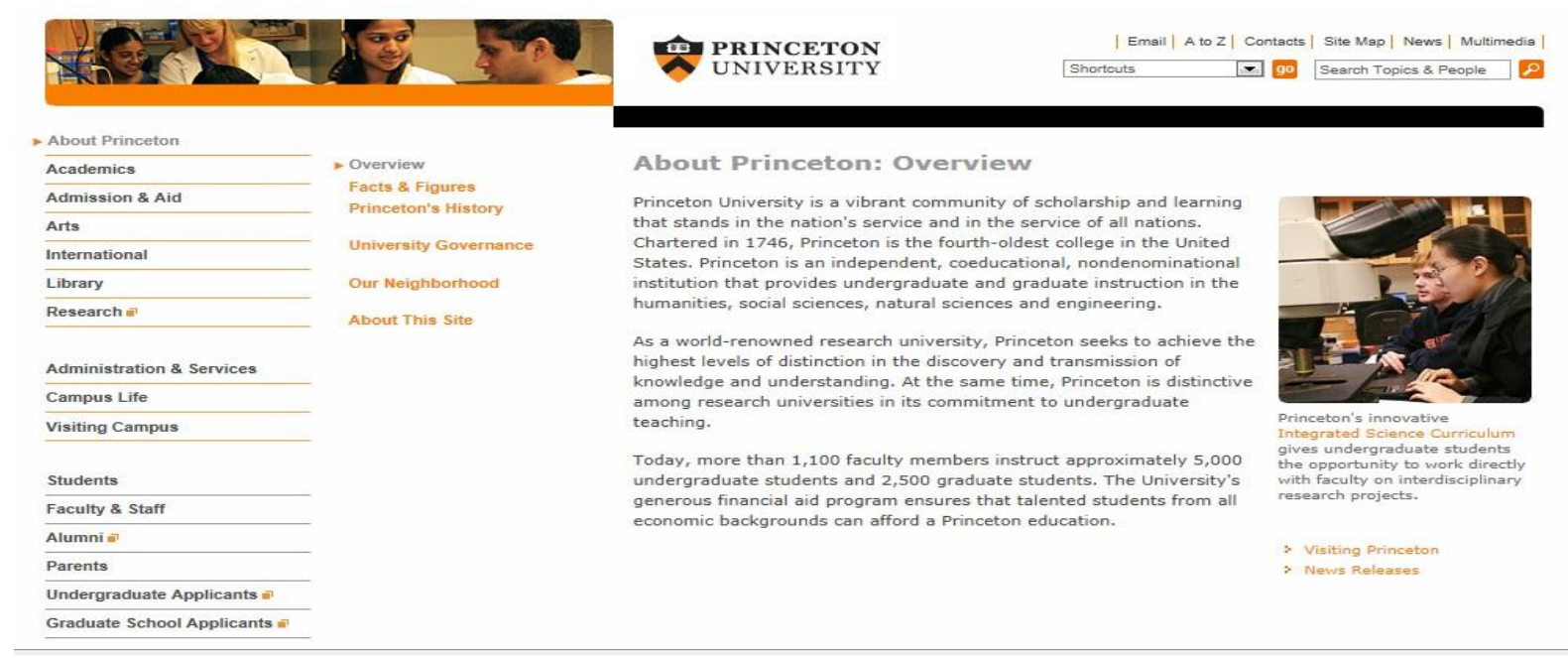

Figure 8. Princeton About Page

The third ranking university was the university of Yale with nine subpages of President's welcome, Yale facts, History, University Leadership and Organization, Governance and Historic Documents, Select Policies andProcedures, Financial Overview, Other Advisory Bodies, and Visiting Yale. The main About page started with listing the academic components of Yale University and the number of students attend there: "Yale University comprises three major academic components: Yale College (the undergraduate program), the Graduate School of Arts and Sciences, and the professional schools...Approximately 11,250 students attend Yale."In the President's Welcome page, the president invited students to visit Yale in person or through the website whileintroducing the university as a place of "compelling change"enjoying"global outlook" and "outstanding research." One the same page,further links were provided to the biography of the president, his speeches and statements and relevant contact information.

Other subpages, that is Yale Facts, History, University's leadership and organization, Governance and historic document, Financial Overview and Visiting Yalewere alike to similar pages of universities described above in terms of content and orienation. However, in its distinct page ofSelect Policies and Procedures, this university was the only university among those studied that provided links to many university-wide policies and regulations of each school. In addition, the page of Other Advisory Bodies, yet another differently titled page, provided someinformation on several advisory boards of Yale whose members were alumni and friends of this university.

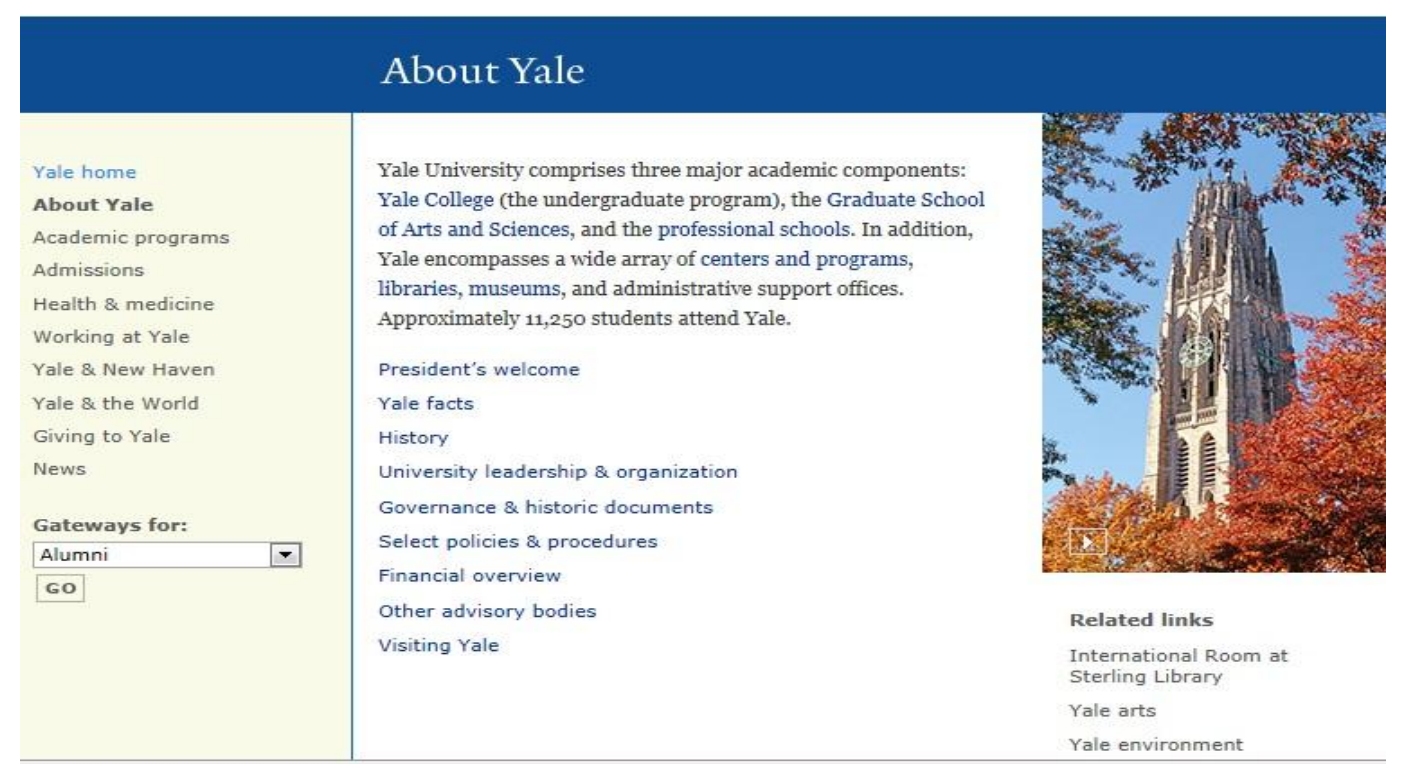

Figure 9. Yale About Page

The About page of Columbia University, the forth ranking university studied here, providedfour major sections of A Brief History, University Administration, Statistics and Facts, and Visiting Columbia's Campuses as its subpages each featured with a picture and some introductory sentences leading the visitors to the corresponding page by a click on the matching link. This page began with the university establishing itslong-standing superior positionin higher education both in the 
nation and around the world for more than 250 years, mentioning its mission statement as including "the commitment to attract and engage the best minds in pursuit of greater human understanding, pioneering new discoveries and service to society."

A very comprehensive account of the history of university wasprovided on the first subpage, namedA Brief History. On the page of University Administration, a brief introduction of the president and all vice-presidents of the university along with a portrait image of eachwas presented. In thesection of Fact and Statistics, like that of other universities some rudimentary statistics related to the number of departments, faculties, programs, students and professors were provided. Finally,on the page of Visiting Columbia's Campuses some information on general campus tours was offered in addition to some furtherlinks titled Visitors Center, Frequently Asked Questions, Maps, Directions and Parking, Columbia Bookstore, It's Happening at Columbia, andSelf-Guided Walking Tour. On the left side of the main page, moreover,some useful links wereplacedas to theMission Statement, Campus Map, Exploring New York City,Columbia Bookstore, and Columbia's Nobel Laureates which provided more guidelines for prospective students of Columbia University.

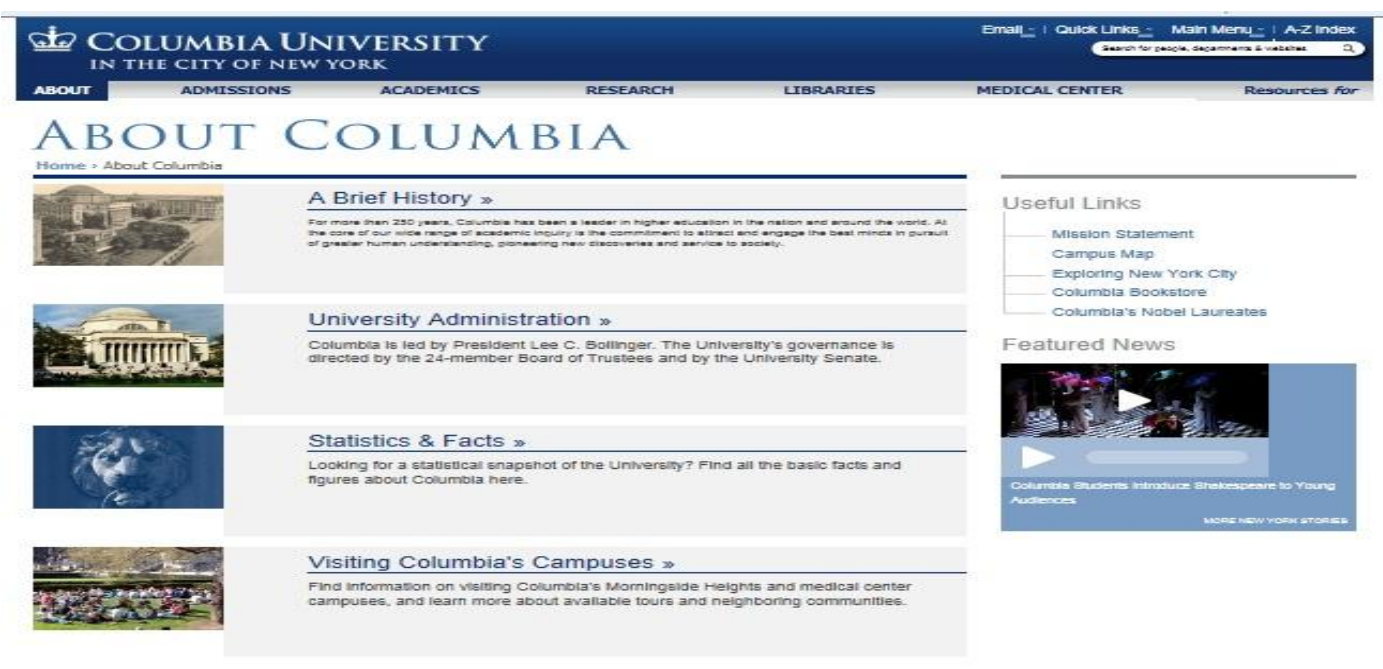

Figure 10. University of Columbia About Page

The Caltech University, the fifth ranking universitysurveyed in this study, appeared to have the most multifaceted About page among 6 American university examined in this study with about 16 sub-pages. The very first part of the About page of this university, contrary to other universities included no primary content but a list of links to all its subpages. In its second main page, Caltech-At-A-Glance, this university stated its mission as to "expand human knowledge and benefit society through research integrated with education." Many of subpages of this university, such as At a Glance, Government Relations, Historical Info, and Information for Visitors weresimilar in content to corresponding pages of other universities. What distinguished this university from other universitieswas the inclusion of new sections such as Commencement, Emergency Information, Executive Education, Scientific Milestones, Media Relations, Outreach, Parents' Newsletter, Public Events, Streaming Theater, Sustainability at Caltech, and Volunteering at Caltech.

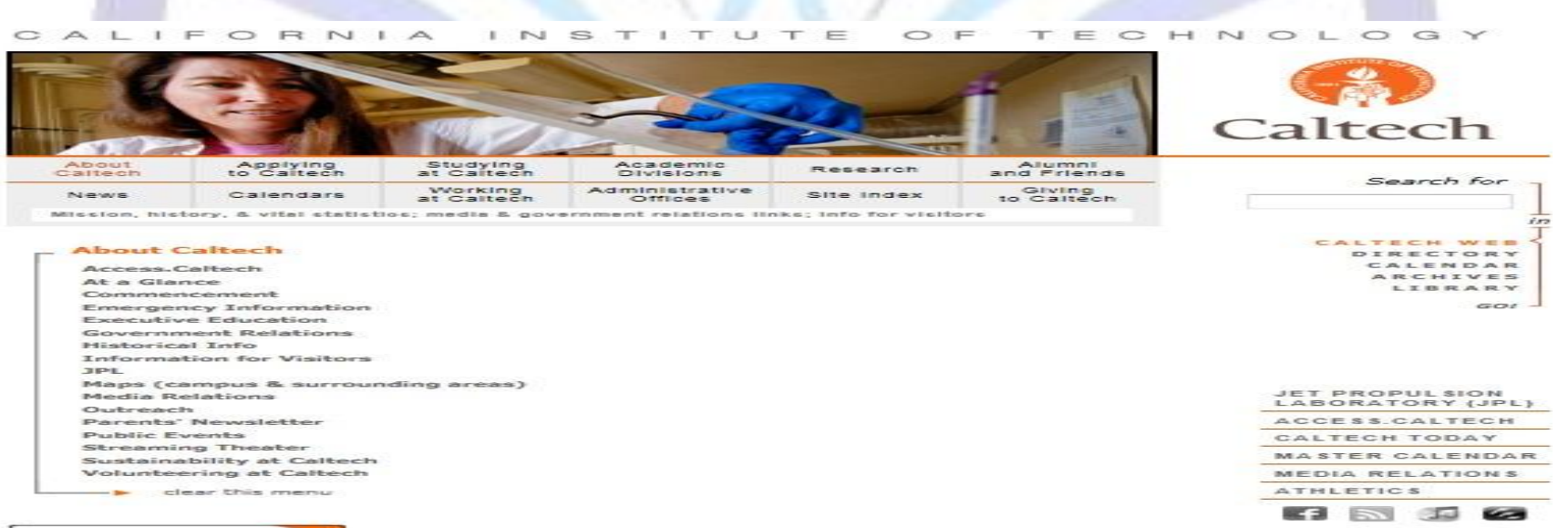

Figure 11. Caltech About Page

The last university examined in this study was MIT. Similar to the About page of Columbia University, the first page of the About page of this universitydidn't not contain extensive primary content but a brief reference to its subpages of Institute Facts, MIT Mission, Institute History, Visiting MIT, Administration, Offices and Services in addition to its mission statement as to "advance knowledge and educate students in science, technology and other areas of scholarship that will best serve the nation and the world in the 21st century - whether the focus is cancer, energy, economics or literature." Furthermore, 
some additional linkswere provided on the same page as to Research and Educational Initiatives, Rankings and Awards, and More News from MITin order to provide more comprehensive information about MIT. On the same page a very short introduction to the president of the university was also provided.

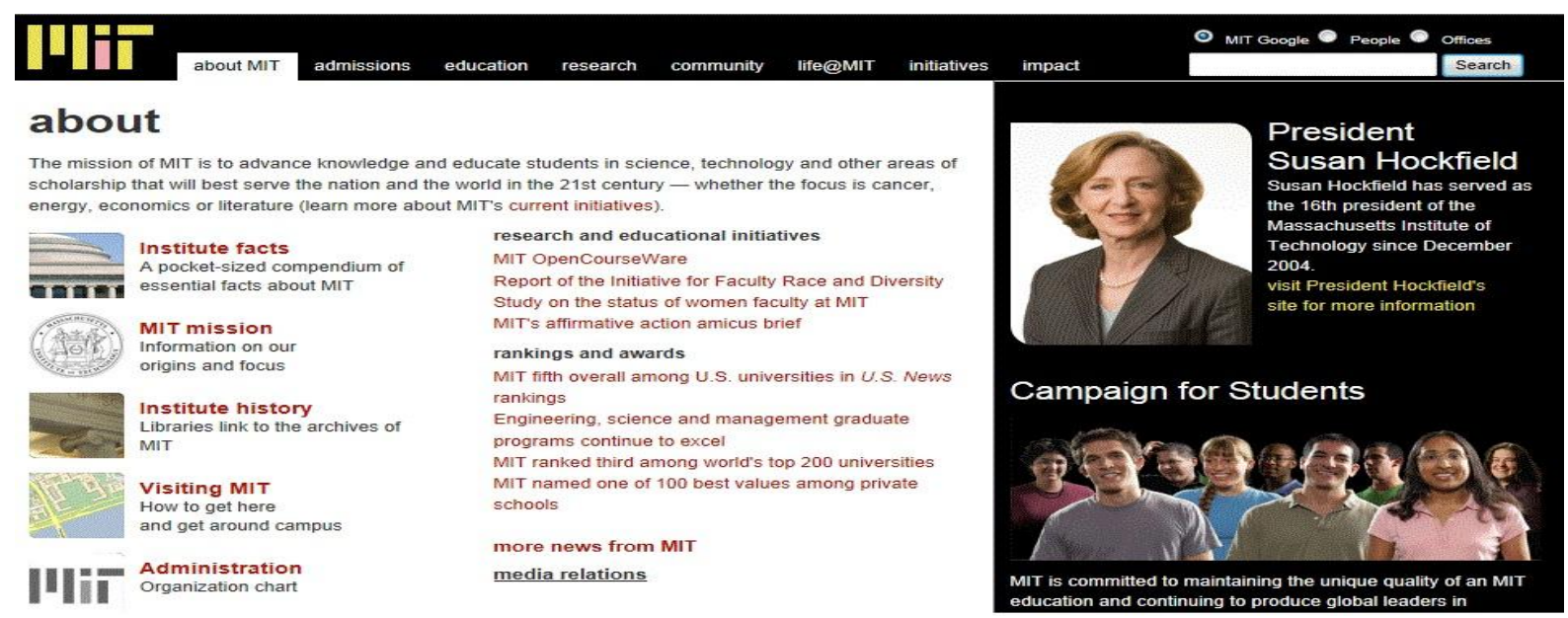

Figure 12. MIT AboutPage

At a glance, just by looking at the number of subpages appeared on the About pages of American and Iranian universities as presented in Table 2, it was apparent that American universities tended to share more details about themselves on their About page. The maximum number of sub-pages appeared on the About page of Iranian university belonged to the University of Tehran with nine subpages.

Table 2. Subpages of the About pages oftop six Iranian and American universities

\begin{tabular}{|c|c|c|c|c|c|}
\hline \multicolumn{3}{|c|}{ Top Iranian Univer sities } & \multicolumn{3}{|l|}{ Top Amer ican Universities } \\
\hline 1. & $\begin{array}{l}\text { Universit y of } \\
\text { Tehran }\end{array}$ & $\begin{array}{ll} & \text { UT Overview } \\
- & \text { Cultural \& Academic Acti vities } \\
- & \text { Facts and Figures } \\
- & \text { Guest House } \\
- & \text { History } \\
- & \text { Libraries and Publication Center } \\
- & \text { Office of International Relations } \\
- & \text { Present Status } \\
& \text { UT Organization } \\
\end{array}$ & 1. & $\begin{array}{l}\text { Harvard } \\
\text { Universit y }\end{array}$ & $\begin{array}{ll}- & \text { About Har var d } \\
\text { - } & \text { Harvard at a Gl ance } \\
\text { - } & \text { FAQ } \\
\text { - } & \text { Mapademic experience } \\
& \text { Harvard Pirecti ons } \\
& \end{array}$ \\
\hline 2. & $\begin{array}{l}\text { Ferdowsi Univer sit y } \\
\text { of Mashhad }\end{array}$ & $\begin{array}{l}\text { - Overvi ew } \\
\text { - A word from the President }\end{array}$ & 2. & $\begin{array}{l}\text { Princeton } \\
\text { Universit y }\end{array}$ & $\begin{array}{ll} & \text { About Princeton U niversity } \\
\text { - } & \text { Overvi ew } \\
\text { - } & \text { Facts \& Figures } \\
\text { - } & \text { Princeton's History } \\
\text { - } & \text { Oniversity Gover nance } \\
\text { - } & \text { About This Site }\end{array}$ \\
\hline 3. & $\begin{array}{l}\text { Tehran universit y } \\
\text { of medical scien ces }\end{array}$ & - Introduction & 3. & $\begin{array}{l}\text { Yale } \\
\text { University }\end{array}$ & $\begin{array}{ll}\text { - } & \text { About Yale } \\
\text { - } & \text { President's welcome } \\
\text { - } & \text { Yale facts } \\
\text { - } & \text { History } \\
\text { - } & \text { University leadership \& organization } \\
\text { - } & \text { Sovernance \& historic documents } \\
\text { - } & \text { Financial over view } \\
\text { - } & \text { Other advisor y bodies } \\
\text { - } & \text { Visiting Yale }\end{array}$ \\
\hline 4. & $\begin{array}{l}\text { ShahidBeheshti } \\
\text { Universit y }\end{array}$ & - $\quad$ About SBU & 4. & $\begin{array}{l}\text { Columbia } \\
\text { University }\end{array}$ & $\begin{array}{ll} & \text { A brief histor y } \\
\text { - } & \text { University Administration } \\
\text { - } & \text { Statistics and facts } \\
\text { Useful links: } & \\
\text { - } & \text { Mission Statement } \\
\text { - } & \text { Campus Map } \\
\text { Exploring New York City } \\
\text { - } & \text { Columbia Books tore } \\
\text { Columbia's Nobel Laureates }\end{array}$ \\
\hline
\end{tabular}




\begin{tabular}{|c|c|c|c|c|c|}
\hline 5. & Shiraz Univer sit y & $\begin{array}{ll}\text { - } & \text { History } \\
\text { - } & \text { Welcome to Shiraz }\end{array}$ & 5. & $\begin{array}{l}\text { Caltech } \\
\text { University }\end{array}$ & $\begin{array}{ll} & \text { Access Caltech } \\
: & \text { At a glance } \\
: & \text { Accommodations } \\
: & \text { Emergency Information } \\
: & \text { Executive Educ ation } \\
: & \text { Government rel ations } \\
: & \text { Iistorical information } \\
: & \text { JPL } \\
& \text { Maps (cam for visitors } \\
& \text { areas) } \\
: & \text { Media Relations } \\
: & \text { Outreach surrounding } \\
: & \text { Parents' Newsl etter } \\
: & \text { Public Events } \\
: & \text { Streaming Theater } \\
& \text { Sustai nability at C altech } \\
& \text { Volunteering at Caltech }\end{array}$ \\
\hline 6. & $\begin{array}{l}\text { Mashhad Universit y } \\
\text { of Medical Sciences }\end{array}$ & $\begin{array}{ll}\text { - } & \text { History } \\
\text { - } & \text { Mission } \\
\text { - } & \text { Overvi ew }\end{array}$ & 6. & MIT & $\begin{array}{ll} & \text { Institute facts } \\
: & \text { MIT mission } \\
: & \text { Institute history } \\
: & \text { Visiting MIT } \\
: & \text { Admi nistration } \\
& \text { Office+ Services }\end{array}$ \\
\hline
\end{tabular}

Other Iranian universities included just one or two subpages in their About page. It was just Mashhad University of Medical Sciences which included three subpages in its About page. For studied American universities, the maximum number of About sub-pages belonged to the University of Caltech with 16 links. The other universities included six to ten subpages on their About page.

The multifaceted and rich nature of About pages of studied American universities, compared to those of Iranian universities could be an indication of extensive and complex relationship American universities have with their website visitors. American universities utilize their institutional websites as a venue to market their educational services to their prospective students, many of whom are international. A great number of international students each year attempt to apply to American universities; thus, they need to acquire the required information about the offered programs through the official websites of those universities. In Iran, however, students are essentially admitted to undergraduate and graduate programs through a centralized entrance exam administered by the Organization of National Educational Measurement. As a result, applicants have little contact with the prospective universities either in person or via their official websites prior to admission. In addition, a very few of admitted students to Iranian universities come from other countries.

The ample amount of information provided by American universities on their About page mightbe an indication of their open attitude towards sharing more about their institutes to their website visitors. It could be a sign of their readiness to be more transparent in communicating the responsibilities they have for their students, facilities they provide, their organizational operations, and expectations they have from their students, and overall, their institutional identity.

Forlranian universities, on the other hand, not sharing extensive contemporary information about theirorganizationcouldbe an indication of a brief restricted relationship of those institutions with their clients. It could also be interpreted as an exercise of power and control and lack of willingness to share up-to-date and all-embracing information about the current status and operations of the university, indicating a top-down pattern of interaction between university authorities and theirclients.

The country of Iran essentially enjoys a hierarchical culture where domineering and authoritarian patterns of interaction infuses every structure of the society including that of higher education. University authorities are principally advocates of top-down patterns of interaction, not prominentlydisplayingreadiness to communicate with theirclients in agenerous and transparent manner.

In addition, looking at the openings of the About pages of these universities, as manifested in Table 3 , some aspects of larger socio-cultural dimensions of the societies these universities are rooted in are revealed. The departure point oflranian universities to introduce themselves was their history, whereas American universities familiarized themselves to their audience with their current status and the academic vision they outline for their prospective students. The islamic Republic of Iran is a very ancient country with a magnificent history and civilization. Thehonor of the glorious past Iranians have used to enjoy has seeped into every corner of people's lives even their use of the contemporary technological advances such as online websites. Top American universities such as Yale or Columbia universities have allocated an extensive part of their About pages to their outstanding histories, however in separately defined pages. They all initiated their About pages with illustrating their current status and their mission statement as to their goal to advance the scholarship of their students.

Among top six Iranian universities, just two of them, i.e., Ferdowsi University of Mashhad, and Mashhad University of Medical Sciences dedicated an explicit part to the mission statement of the university, most probably owing to their attempt to attract international students to their academic programs, trying to conform to international academic norms. The president of the Ferdowsi University of Mashhad, for instance, expressed this very goal in on this page: "FUM is now aiming at placing itself in an outstanding position by paving the way for getting more overseas students together and creating a friendly atmosphere amongst younger generations" recruiting international students from 17 nationalities. 
Table 3.The openings of sixtop Iranian and American universities

\begin{tabular}{|c|c|c|c|c|c|}
\hline \multicolumn{6}{|c|}{ Openings } \\
\hline \multicolumn{3}{|c|}{ Top Iranian Univers ities } & \multicolumn{3}{|c|}{ Top American Universities } \\
\hline 1 & $\begin{array}{l}\text { University of } \\
\text { Tehran }\end{array}$ & $\begin{array}{l}\text { Rooted in JondiShapur University which goes } \\
\text { back over 2,000 years, the University of } \\
\text { Tehran (UT) in its traditional formwas } \\
\text { established seven centuries ago. }\end{array}$ & 1. & $\begin{array}{l}\text { Harvard } \\
\text { University }\end{array}$ & $\begin{array}{l}\text { Harvard University is devoted to } \\
\text { excellence in teaching, learning, and } \\
\text { research, and to developing leaders } \\
\text { in many disciplines who make a } \\
\text { difference globally. }\end{array}$ \\
\hline 2 & $\begin{array}{l}\text { Ferdowsi } \\
\text { University of } \\
\text { Mashhad }\end{array}$ & $\begin{array}{l}\text { Ferdowsi University of Mashhad (FUM) is a } \\
\text { state university named after the great epic } \\
\text { poet and scholar Ferdowsi whose Shahnameh } \\
\text { (The Book of Kings) is a well-known classical } \\
\text { chef-d'oeuvre in Persian literature }\end{array}$ & 2. & $\begin{array}{l}\text { Princeton } \\
\text { University }\end{array}$ & $\begin{array}{l}\text { Princeton University is a vibrant } \\
\text { community of scholarship and } \\
\text { learning that stands in the nation's } \\
\text { service and in the service of all } \\
\text { nations. }\end{array}$ \\
\hline 3 & $\begin{array}{l}\text { Tehran } \\
\text { university of } \\
\text { medical } \\
\text { sciences }\end{array}$ & $\begin{array}{l}\text { This introduction provides basic information } \\
\text { about Tehran University of Medical Siences } \\
\text { and Health Services(T.U.M.S.); courses } \\
\text { off ered, requirements for admission, a flavor of } \\
\text { life on the campus, and the academic, sport, } \\
\text { and social facilities available }\end{array}$ & 3. & $\begin{array}{l}\text { Yale } \\
\text { University }\end{array}$ & $\begin{array}{l}\text { Yale University comprises three } \\
\text { major academic components: Yale } \\
\text { College (the undergraduate } \\
\text { program), the Graduate School of } \\
\text { Arts and Sciences, and the } \\
\text { professional schools. }\end{array}$ \\
\hline 4 & $\begin{array}{l}\text { ShahidBeheshti } \\
\text { University }\end{array}$ & $\begin{array}{l}\text { ShahidBeheshti University (SBU), established } \\
\text { in 1959(The ex- National University of Iran), } \\
\text { started its academic life in } 1960 \text { w th only } 174 \\
\text { students in two faculties: Faculty of } \\
\text { Architecture and Urban Planning and Faculty } \\
\text { of Banking and Economics. }\end{array}$ & 4. & $\begin{array}{l}\text { Columbia } \\
\text { University }\end{array}$ & $\begin{array}{l}\text { For more than } 250 \text { years, Columbia } \\
\text { has been a leader in higher } \\
\text { education in the nation and around } \\
\text { the world }\end{array}$ \\
\hline 5 & $\begin{array}{l}\text { Shiraz } \\
\text { University }\end{array}$ & $\begin{array}{l}\text { The initial nucleus of Shiraz University was } \\
\text { formed in } 1946 \text { w ith the establishment of the } \\
\text { junior College of Health w hich aimed at } \\
\text { training specialists in the Medical Sciences } \\
\text { during a four year program. }\end{array}$ & 5. & $\begin{array}{l}\text { Caltech } \\
\text { University }\end{array}$ & $\begin{array}{l}\text { The mission of the California Institute } \\
\text { of Technology is to expand human } \\
\text { know ledge and benef it society } \\
\text { through research integrated with } \\
\text { education }\end{array}$ \\
\hline 6 & $\begin{array}{l}\text { Mashhad } \\
\text { University of } \\
\text { Medical } \\
\text { Sciences }\end{array}$ & $\begin{array}{l}\text { Mashhad Faculty of Medicine was officially } \\
\text { opened on Nov. } 23,1949 \text { by DrZanganeh, the } \\
\text { minister of culture. }\end{array}$ & 6. & Мा & $\begin{array}{l}\text { The mission of MIT is to advance } \\
\text { know ledge and educate students in } \\
\text { science, technology and other areas } \\
\text { of scholarship thatw ill best serve the } \\
\text { nation and the world in the } 21 \text { st } \\
\text { century - whether the focus is } \\
\text { cancer, energy, economics or } \\
\text { literature }\end{array}$ \\
\hline
\end{tabular}

After analyzing the content of the About pages of the selected universities, it was found that the existing differences observed in the way top six Iranian and American universities present themselves on theirAbout page could be traced back to larger socio-cultural driving forces operating in those societies.

\section{CONCLUSION}

The World Wide Web has modified existing genres (Crowston, and Williams, 1997) giving rise to new genres including home pages,brochures, resources, catalogues, search engines, andgames, characterized according to content, formand functionality (Shepherd and Watters, 1999). What matters most for studying and identifying emergent cyber genres is document characteristics and thecontext in which the document is used (Crowston and Kwasnik, 2004). Whether About pages of the official websites of academic institutions including universities constitute a particular genre requires more comprehensive studies. Nonetheless, this study with itsattempt to examine the About pages of top six Iranian and American universities revealed significant differences in the way these universities represented themselves online. Further detailed and comprehensive studies, however, are required to explore such differences in a more thorough manner.

\section{REFERENCES}

1. Abrahamson, T. 2000. "Life and death on the Internet: To web or not to web is no longerthe question", The Journal of College Admissions, 168, 6-11. 


\section{ISSN 2321-1091}

2. Adelman, C. 2006. "How to design a web site that welcomes prospective applicants", Chronicle of Higher Education, 53(10), B26.

3. Anctil, E. J. 2008. "Selling higher education: marketing and advertis ing",ASHE HigherEducation Report, $34(2), 1$ 121.

4. Ashburn, E. 2007."Prospective students rely on campus visits and web sites to leamaboutcolleges, report says",Chronicle of Higher Education, 53(38), 39.

5. Askehave, I. 2007. "The impact of marketization on higher education genres - theinternational student prospectus as a case in point", Discourse Studies, 9(6), 723-742.

6. Boyles, D. R. 2007. Marketing sameness: Consumerism, commercialism, and the statusquo. In J. C. Smart (Ed.), Higher education: Handbook of theory and research(Vol. 22, pp. 537-582). New York, NY: Agathon Press.

7. Carlson, S. 2010. "How to build a perception of greatness",Chronicle of HigherEducation, 57(13), A1-A13.

8. Chiper, S. (2006). "The discourse of Romanian universities", Journal of OrganizationalChange Management, 19(6), 713-24.

9. Crowston, K. and Kwasnik, B.H. 2004. "A Framework for Creating a Facetted Classification for Genres:Addressing Issues of Multidimensionality", Proceedings of the 37th Hawaii International Conference on System Sciences, Los Alamitos: IEEE Press.

10. Crowston, K. and Williams, M. 1997. "Reproduced and Emergent Genres of Communication on the World Wide Web",The Information Society, 16(3), 201-215.

11. DiMaggio, P. J. and Powell, W. W. 1983. "The iron cage revisited: Institutionalis omorphism and collective rationality in organizational fields", AmericanSociological Review, 48(2), 147-160.

12. Fairclough, N. 1993."Critical discourse analysis and the marketization of publicdiscourse: The universities",Discourse and Society, 4, 122-169.

13. Fairclough, N. 1995.Media discourse. London, UK: Longman.

14. Fairclough, N. 2001.Language and power(2nd ed.). New York, NY: Longman.

15. Fairclough, N.and Wodak, R. 1997. Critical Discourse Analysis.InT.VanDijk (Ed.), Discourse as social interaction (pp.258-284). London: Sage.

16. Hall, S. 1997. The spectacle of the "other." In S. Hall (Ed.), Representation: Culturalrepresentations and signifying practices (pp. 223-279). London, UK: SagePublications.

17. Hartley, M. and Morphew, C. 2008. "What's being sold and to what end? A contentanalys is of college viewbooks",Joumal of Higher Education, 79(6), 671-691.

18. Hossler, D. 1999. Using the Internet in college admissions: Strategic choices. Journal ofCollege Admissions, 162, 12-19.

19. Kress, G. and Van Leeuwen, T. 2006.Reading images: The grammar of visual design .London, UK: Routledge.

20. Kotler, P. and Fox, K. F. A. 1995.Strategic marketing for educational institutions $\left(2^{\text {nd }}\right.$ ed.). Englewood Cliffs, NJ: Prentice Hall.

21. Luhmann, N. 2000.Organis ation und Entscheidung.Opladen: Westdeuts cherVerlag.

22. Lynch, P.J. and Horton, S. 2009. "Web Style Guide:Basic Design Principles for Using English for Academic Purposes ",A Guide for Students in Higher Education Language Value 2, (1), 144-151.

23. McKnight, O., andPaugh, R. 1999.Advertising slogans and university marketing: Anexploratory study of brand-fit and cognition in higher education. Proceedings ofthe 1999 Symposium for the Marketing of Higher Education, American Marketing Association, Chicago, pp. 50-55.

24. Seidl, D. 2005. Organisational Identity and Self-Transformation: An Autopoietic Perspective. Aldershot: Ashgate.

25. Shepherd, M., andWatters, C. 1999. The Functionality Attribute of Cybergenres, Proceedings of the $32^{\text {nd }} \mathrm{Hawaii}$ International Conference on System Sciences, Los Alamitos: IEEE Press

26. Urciuoli, B. 2003."Excellence, leadership, skills, diversity: Marketing liberal arts education”, Language \& Communication, 23(3-4), 385-408.

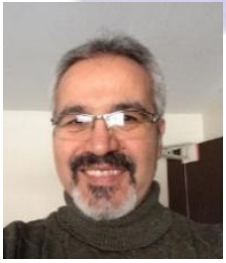

\section{Reza Ghafar-Samar}

Biodata:Reza Ghafar-Samar is an assistant professor of (Socio) linguistics and Second Language Acquisition at TarbiatModarres University, Tehran, Iran. He holds a Ph.D. from University of Ottawa, Canada in Applied-Sociolinguistics. He specializes in Sociolinguistics (Variation Theory, Bilingualism, and Language change) and its application in Second/Foreign Language Acquisition. He is the author of numerous articles appearing as book chapters or in joumals such as International Joumal of Bilingualism.

Email: rgsamar@modares.ac.ir

Contact Number: 98-(21) 82883664; 98-912-5179164

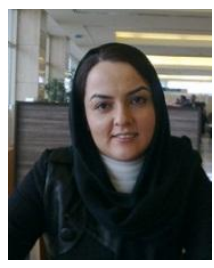

\section{ShabnamMokhtarnia}

Biodata: Shabnam Mokhtarniais a Ph.D. graduate in TEFL from TarbiatModarres University. She has published articles in areas such as computer-assisted reading and writing, English learner identity, the role of culture in ELT, and pragmatics.

Email: smokhtarnia@gmail.com

Contact Number: 98-912-5604424 